\title{
Measurement of DNA damage in bladder cancer patients by alkaline comet assay
}

\author{
Jahidul Islam ${ }^{1}$ Yearul Kabir
}

Cite this article: Islam J, Kabir Y: Measurement of DNA damage in bladder cancer patients by alkaline comet assay . Ann Urol Oncol 2019; 2(2): 15-21. https:// doi.org/10.32948/auo.2019.12.26

\begin{abstract}
Introduction Bladder cancer is the most common cancer of the urinary tract. DNA damage is responsible for genomic instability, which is a hallmark of bladder carcinogenesis. Cigarette smoking induced DNA damage is one of the major risk factors associated with this disease. Methods We used the alkaline comet assay to measure DNA damage in peripheral blood lymphocytes from 38 bladder cancer patients and 26 healthy control subjects. All subjects provided personal information, including smoking history. DNA damage was quantified by calculating the \%tail DNA (\%TD) and olive tail moment (OTM) parameter.

Results It was found that patients (\%TD $20.09 \pm 1.67$ and OTM $31.31 \pm 2.82$ ) had significant DNA damage compared with control subjects (\%TD $2.70 \pm 0.48$ and OTM $9.34 \pm 1.30$ ). Besides, patients with extensive smoking history had higher DNA damage compared to nonsmoker patients.

Conclusion This is the first attempt to use alkaline comet assay to evaluate DNA damage in Bangladeshi bladder cancer patients. The results of this study may emphasize to use ACA for routine DNA damage detection, which could be used as a prognostic biomarker of bladder cancer.
\end{abstract}

Key words bladder cancer, comet assay, DNA damage, cigarette smoking

\footnotetext{
1. Department of Biochemistry and Molecular Biology, University of Dhaka. Dhaka-1000. Bangladesh. Correspondence: Yearul Kabir (Department of Biochemistry and Molecular Biology, University of Dhaka, Dhaka 1000, Bangladesh; Email: ykabir@ yahoo.com; ykabir@du.ac.bd).
} 


\section{Introduction}

Bladder cancer (BC) is a prevalent malignant tumor of the urinary tract and ninth most predominant cancer diagnosed worldwide [13]. $\mathrm{BC}$ remains an important health problem as it's occurrence rate is three to four times higher in men than in women and estimated 165,000 deaths annually $[1,4,5]$. BC is categorized to two major groups depending on tumor stage, A) non-muscle invasive bladder cancer (NMIBC), which is either limited to bladder mucosa (carcinoma in situ (CIS)-or stage Ta, 5-year survival rate over $95.4 \%$ ) or submucosa (stage T1, 5-year survival rate of nearly $88 \%$ ) and B) muscle-invasive bladder cancer (MIBC) (stage T2, T3 and $\mathrm{T} 4$, representing 5-year survival rates of $69.4 \%, 34.9 \%$ and $4.8 \%$, respectively) $[1,4]$. Epidemiological studies suggest that cigarette smokers have 2- to 4-fold higher incidence of $\mathrm{BC}$ than nonsmokers [6-8]. As cigarette smoke contains numerous carcinogens including polycyclic aromatic hydrocarbons (PAH), aromatic amines and $\mathrm{N}$-nitroso compounds, as well as reactive oxygen species (ROS) which are responsible for the DNA damages like chemical change of bases, single-strand breaks (SSBs), double strand breaks (DSBs) and finally lead to genomic instability and drive the tumor phenotype [9-14]. Besides, BC is substantially increased by carcinogen exposed people especially due to xenobiotic metabolizing enzyme polymorphism for example tumor protein 53 (TP53), N-acetyl transferase 2 (NAT2), glutathione S-transferase P1 (GSTP1) and human 8-oxoguanine DNA glycosylase 1 (OGG1) polymorphism [5, 15-17]. Thus, it is important to detect the DNA damage in different geographic region population due to their distinctive combination of polymorphic traits which may alter genetic susceptibility as well as response to drugs, chemicals, and carcinogens.

The alkaline comet assay (ACA) is an effective technique in determining various kinds of DNA damages like DSBs, SSBs, alkali-labile sites, incomplete repair sites, and cross-links both in vitro and in vivo [12, 18-21]. This is the first report using the ACA method to detect DNA damage in Bangladeshi bladder cancer patients and the basal DNA damage of the healthy subjects.

\section{Materials and methods}

\section{Chemicals}

Normal melting point (NMP) agarose, low melting point (LMP) agarose, N-lauryl sarcosinate, silver nitrate (AgNO3), ethylenediaminetetraacetic acid (EDTA) were purchased from Sigma (St. Louis, USA). Sodium chloride (NaCI), sodium hydroxide $(\mathrm{NaOH})$, dimethyl sulfoxide (DMSO) were supplied by LOBA chemie (India). All the other chemicals were obtained locally and were of analytical grade.

\section{Case - control survey study: Selection of study population}

A total of 64 unrelated Bangladeshi individuals were enrolled in this study. Among the study participants, 38 (59.38\%) were patients with bladder carcinogenesis and 26 (41.94\%) were healthy controls. BC patients were recruited from the urology department of various medical colleges in Dhaka city. Healthy controls were also recruited from different hospitals of Dhaka city where they came for regular health checkup without any history of cancer or other chronic diseases. After getting full verbal consent from the participants, three milliliter of blood was collected in an EDTA containing tube. Detailed data along with clinical data on tumor characteristics and therapy regimens were collected from patient records in hospital. All BC patients were categorized as NIMBC and MIBC. This study was approved by the ethical committee of Bangladesh medical research council under the guidelines of the ministry of health and family welfare.

\section{Questionnaire and investigation}

All study subjects completed a structured questionnaire covering information on age, residential, occupational, and smoking history. As part of the interview, participants were asked to provide a detailed lifetime smoking history (non- and current). Patients those who smoke 25 or more cigarettes a day were termed as heavy smoker (HS) and those who smoke equal or less than 24 cigarettes per day were termed as lighter smoker (LS) [22].

\section{Estimating DNA damage by ACA technique}

The ACA technique was carried out according to the protocol described by Tice et al. (2000) with slight modification [21]. Briefly, $20 \mu \mathrm{l}$ whole blood was used per slide, in where slides were previously coated with $1 \%$ NMP agarose. Blood cells containing slides were then embedded in $0.7 \%$ LMP agarose and subsequently lysed by lysis solution consisting of $\mathrm{NaCl}(2.5 \mathrm{M})$, Na2EDTA (100mM), Trisma base (10mM), NaOH (200 mM), N-lauroylsarcosine (1.0\%). DMSO (10\%) and Triton X-100 (1.0\%). For SSBs analysis, the DNA was unwounded by freshly prepared cold alkaline electrophoresis buffer $(1 \mathrm{mM}$ Na2EDTA and $300 \mathrm{mM} \mathrm{NaOH} ; \mathrm{pH} 13.0)$ and then electrophoresed in the same buffer $\left(24 \mathrm{~V} ; 300 \mathrm{~mA}\right.$ at $\left.4^{\circ} \mathrm{C}\right)$. For DSBs, the DNA was unwinding by using neutralization buffer ( $0.4 \mathrm{M}$ Trisma base; $\mathrm{pH} 7.5)$ and electrophoresed in the same buffer (24 V; $300 \mathrm{~mA}$ at $4^{\circ} \mathrm{C}$ ). After silver staining, cell images were captured and visualized by conventional light microscope [(Motic-BA200) (400×magnification)] equipped with CCD camera (Nikon Cool Pix 99F) [23]. The images were analyzed by using the software named computer assay software project (CASP, version 1.2.2) [24]. A total of 100 cells per slide and 2 slides per sample were used to quantify the DNA damage. The extent of comet tail formation is proportional to the amount of DNA damage present. Thus, the higher the values of \%TD and OTM, as computed by the software, the higher the level of DNA damage was calculated [19, 25].

\section{Statistical analysis}

All values were presented as mean \pm SEM. Differences between different variables were analyzed using parametric student's t-test and one-way analysis of variance (ANOVA) followed by Tukey's multiple comparison test. A value of $\mathrm{P}<0.05$ was considered to be statistically significant.

\section{Results}

\section{Results from survey investigation}

Distribution of study subjects according to gender, age, occupation, residence and smoking status were presented in Table 1 . The age (mean $\pm \mathrm{SD}$ ) of control and bladder cancer patients were $50.0 \pm$ 6.87 and $61.48 \pm 12.89$ years, respectively $(\mathrm{P}<0.05)$. There were no significant differences in occupation and residency between patients and the control subjects. Flow chart for the study is shown in Figure 1.

\section{DNA damage analysis based on age and disease category}

Figure 2(a) and 2(b) describe both the \%TD and OTM values between control $(n=26)$ and cancer patients $(n=38)$. The patients group displayed significantly higher levels of DNA damage than control subjects. The ranges of \%TD in control and patients were $2.70 \pm 0.48$ vs $20.09 \pm 1.67$, while OTM value were in $9.34 \pm 1.30$ 


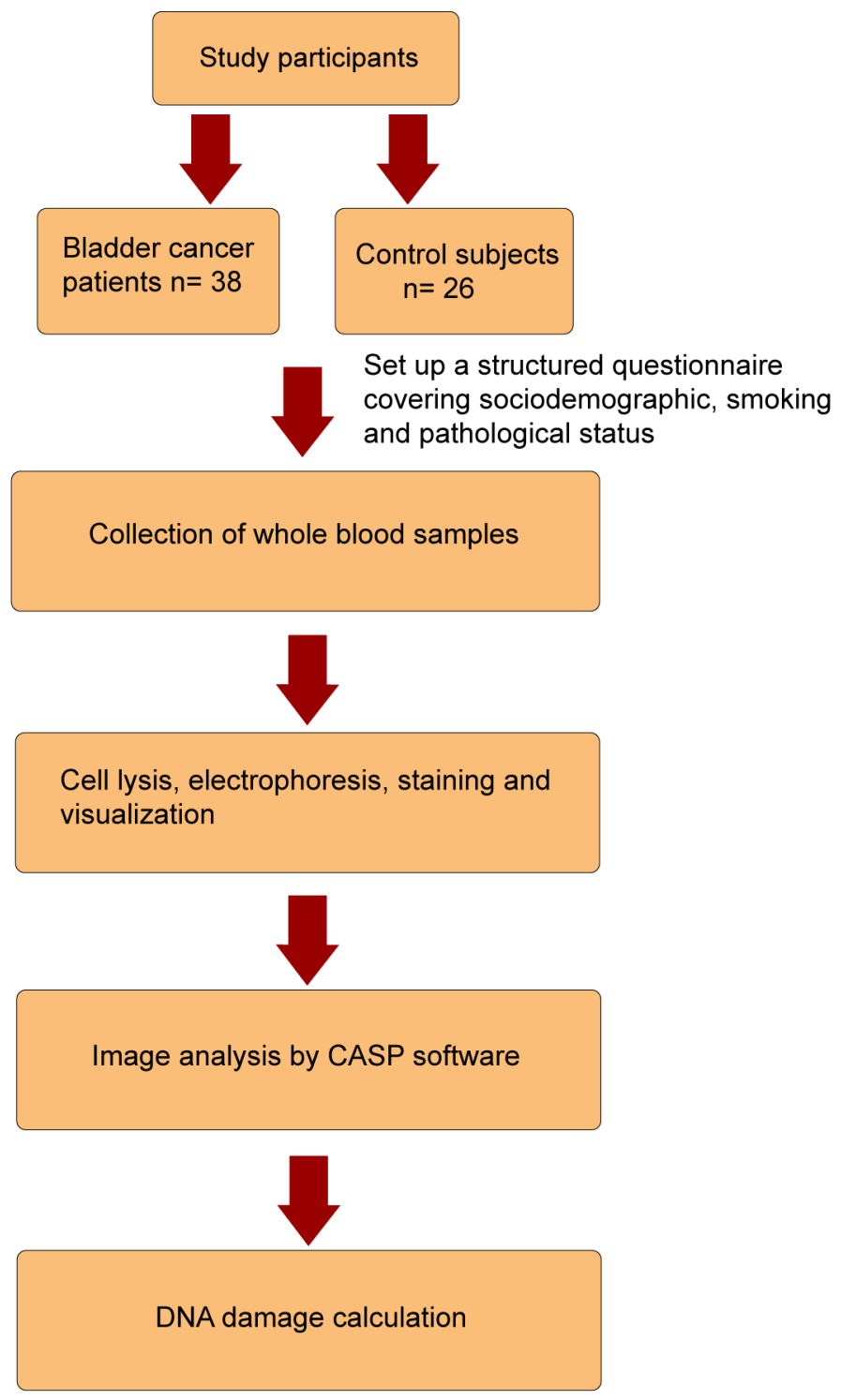

Figure 1. Flow chart for the study.

vs $31.31 \pm 2.82$. There was significant difference both in $\% \mathrm{TD}$ and OTM value between control and patients $(\mathrm{P}<0.05)$. To determine the effect of age on DNA damage, all groups were divided into two categories based on age below and above 50. From Figure 3 (a) and $\mathbf{3}$ (b), there were no significant differences in \% $\mathrm{TD}$ and OTM value in control groups (control $<50$ vs control $>50$ ), as well as in patient groups itself (patients $<50$ vs patients $>50$ ). Cancer patients over 50 , had predominately higher DNA damage compared to control over 50 (TD, $3.23 \pm 0.92 \mathrm{vs,} \mathrm{P}<0.05$ and for OTM, $10.90 \pm 2.10$ vs $33.44 \pm 4.02, \mathrm{P}<0.05)$ and control below 50 $(\% \mathrm{TD}, 2.37 \pm 0.51$ vs $22.11 \pm 2.15, \mathrm{P}<0.05$ and for OTM, $8.36 \pm$ 1.60 vs $33.44 \pm 4.02, \mathrm{P}<0.05$ ). Same phenomenon was observed in cancer patients below 50 compare to both control below 50 (\%TD, $2.37 \pm 0.51$ vs $16.22 \pm 2.21, \mathrm{P}<0.05$ and for OTM, $8.36 \pm 1.60$ vs $27.20 \pm 2.55, \mathrm{P}=.05)$ and control over $50(\% \mathrm{TD}, 3.23 \pm 0.23 \mathrm{vs}$ $16.22 \pm 2.21, \mathrm{P}<0.05$, and for OTM, $10.90 \pm 2.10$ vs $27.20 \pm 2.55$, $\mathrm{P}<0.05)$. Both NMIBC $(\mathrm{n}=22)$ and MIBC $(\mathrm{n}=16)$ group had found same level of DNA damage $(\% \mathrm{TD}, 18.72 \pm 1.92$ vs $20.52 \pm$ 2.77 and for OTM, $31.52 \pm 4.25$ vs $29.84 \pm 4.64)$.
From Figure 4(a) and 4(b), DNA damages were analyzed on the basis of smoking status in control and patient group, in where patient group was divided into two groups named patients (nonsmoker) and patients (smoker). Patients with smoking history $(\mathrm{n}=20)$ had significant DNA damage compare to patients with no smoking history $(\mathrm{n}=18),(\% \mathrm{TD}, 23.85 \pm 2.26$ vs $17.36 \pm 2.20, \mathrm{P}$ $<0.05$ and for OTM, $38.36 \pm 4.52$ vs $26.59 \pm 1.97, \mathrm{P}<0.05$. Both $\% \mathrm{TD}$ and OTM value were found higher in patients of smoker and non- smoker compared with control $(\mathrm{n}=26)$. On the other hand, Figure 5 (a) and $\mathbf{5}$ (b), described the DNA damage of the smoker patients with their smoking intensity. Patients with heavy smoking history, HS $(\mathrm{n}=9)$ had a high DNA damage compared to patients with lighter smoker, LS $(n=11)$ only in \% $\%$ Dut not in OTM parameter $(\% \mathrm{TD}, 29.21 \pm 3.31$ vs $18.36 \pm$ vs $2.02, \mathrm{P}<0.05$ and for OTM, $45.82 \pm 6.44$ vs $33.41 \pm 4.13$ ). Overall, the present study indicated that cancer patients with a long history of smoking exposure had significant DNA damage compared to the control subjects.

\section{Discussion}


Table 1: Characteristics of study subjects

\begin{tabular}{|c|c|c|c|}
\hline Variable & Control $(n=26, \%)$ & Patients $(n=38, \%)$ & P-value \\
\hline \multicolumn{4}{|l|}{ Gender } \\
\hline Male & $23(88.46)$ & $37(97.37)$ & $n s$ \\
\hline Female & $3(11.54)$ & $1(2.63)$ & \\
\hline Age (Year)ף & $50.0 \pm 6.87$ & $61.48 \pm 12.89$ & * \\
\hline \multicolumn{4}{|l|}{ Smoking status } \\
\hline Smoker & $0(0.00)$ & $22(57.89)$ & $*$ \\
\hline Non-smoker & $26(100)$ & $16(42.11)$ & \\
\hline \multicolumn{4}{|l|}{ Occupation } \\
\hline Dye worker & $0(0.00)$ & $4(10.53)$ & $n s$ \\
\hline Farmer & $3(11.54)$ & $6(15.79)$ & \\
\hline Others & $23(88.46)$ & $28(73.68)$ & \\
\hline \multicolumn{4}{|l|}{ Residence } \\
\hline Urban & $19(73.08)$ & $21(55.26)$ & $n s$ \\
\hline Rural & $7(26.92)$ & $17(44.74)$ & \\
\hline
\end{tabular}

$* \mathrm{P}<0.05$ was taken as level of significance. Fisher's and chi-square tests were performed to calculate the statistical significance.

qValues are mean \pm SD. 'ns'= not significant.

Bladder Cancer is a leading cause of cancer-related deaths globally and about $50 \%$ of $\mathrm{BC}$ patients are cigarette smokers. The intensity and duration of smoking has been shown to affect the grade and stage of the $\mathrm{BC}$ and heavy smokers have more aggressive cancer phenotypes [26]. Smokers with BC are found to have resistance to chemotherapy also [27]. About $75 \%$ of newly diagnosed BC are generally noninvasive, although this type has a high rate of recurrence and progression despite the use of local therapy [2]. Cigarette smoke containing aromatic and heterocyclic amines (such as benzidine, 2-naphthylamine, 4-aminobiphenyl) exacerbate the bladder carcinogenesis $[16,28]$. Generally long term carcinogenic compounds exposure either directly or via metabolic activation can reduce the DNA repair capacity, which ultimately increase the BC susceptibility [7, 29-31]. Thus, the cellular abilities of repairing the DNA damages are closely linked to the possibilities of cancer

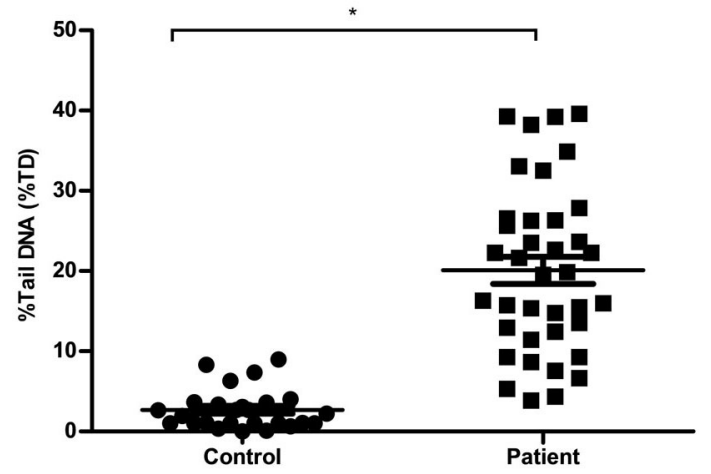

A

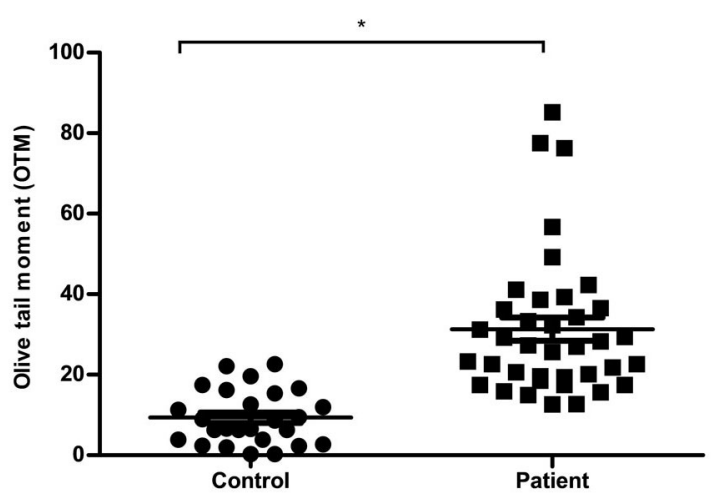

B

Figure 2. Observed DNA damage. (A) \%Tail DNA (\%TD), and (B) Olive tail moment (OTM) between control subjects and patients. Statistical difference was tested by Student $t$ test. $* \mathrm{P}<0.05$ was taken as level of significance. 

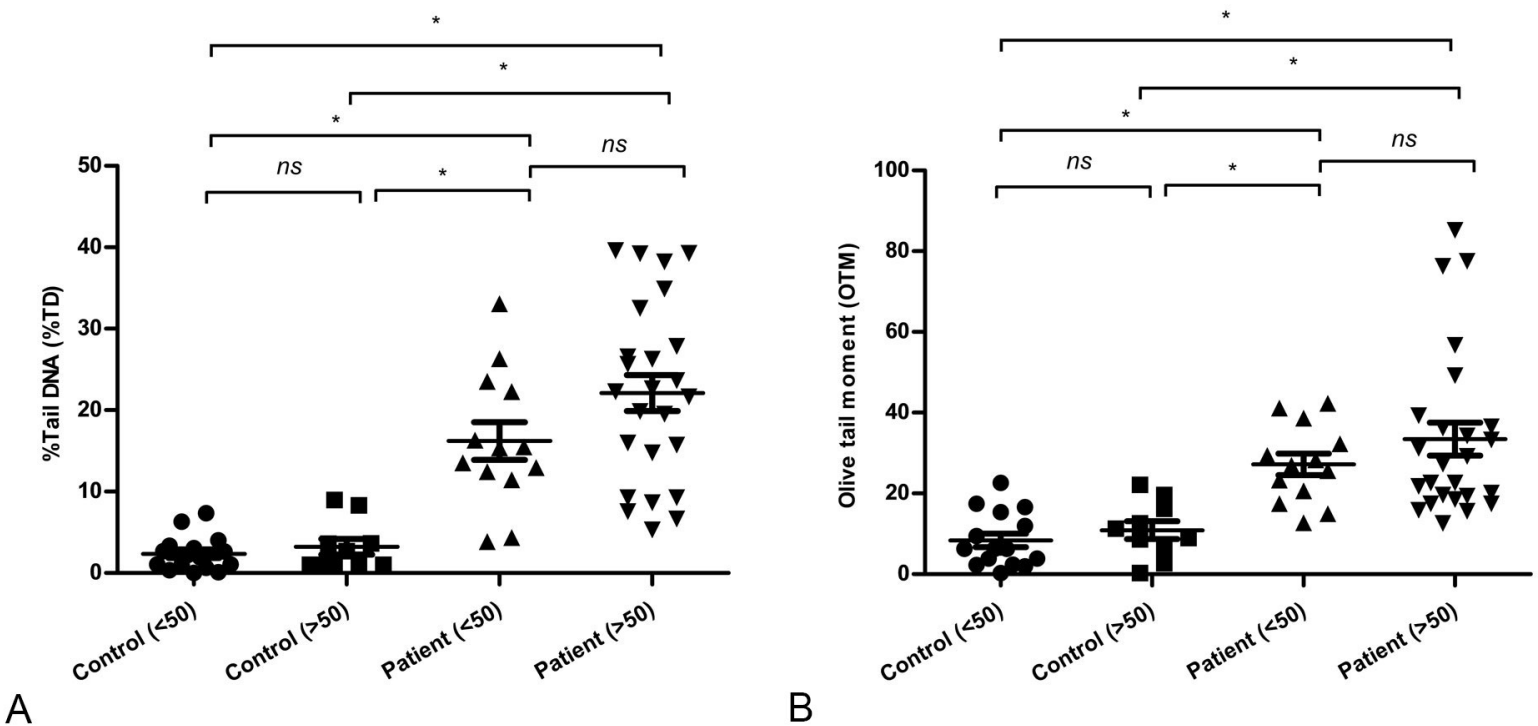

Figure 3. Observed DNA damage based on age. (A) \%Tail DNA (\%TD), and (B) Olive tail moment (OTM) for control subjects (both below 50 and over 50), patients (both below 50 and over 50). Statistical difference was tested by one-way ANOVA followed by Tukey's multiple comparison test. $* \mathbf{P}<0.05$ was taken as level of significance. ' $n s$ ' $=$ not significant.

development. Most of the bladder tumors have complex genomes with a high prevalence of mutational hotspots. Previously, we reported that cigarette smokers having Pro/Pro genotypes at position 72 in TP53 gene and NAT-2 slow genotype increased the $\mathrm{BC}$ risk in Bangladeshi population [5, 16]. Thus, there is a strong relationship in genetics and carcinogen exposure due to working or environmental condition in occurring bladder carcinogenesis [32]. As genomic instability due to DNA damage plays a prominent role in carcinogenesis initiation, it is important to quantify DNA damage to evaluate the disease progression [33].

ACA technique has been broadly recognized as a simple, sensitive, and rapid method [31, 34, 35]. It has numerous benefits especially only a thousand cells are needed for this assay or even the cells do not need to be tagged with a radioisotope and DNA damage can be quantified in any nucleated cell [36]. Here, both comet parameters \%TD and OTM were found higher in cancer patients compared to control subjects, which indicated that higher level of genotoxicity occurred in BC patients. Comet parameters indicate not only the DNA damage but also the DNA repair capacity as because the low damage level as assessed experimentally in an individual may be due to an actual low number of lesions or of the high efficiency of repair. Among the SSBs and DSBs, DSBs were supposed to be the critical cytotoxic lesion, which were involved in mutagenesis, chromosomal
A

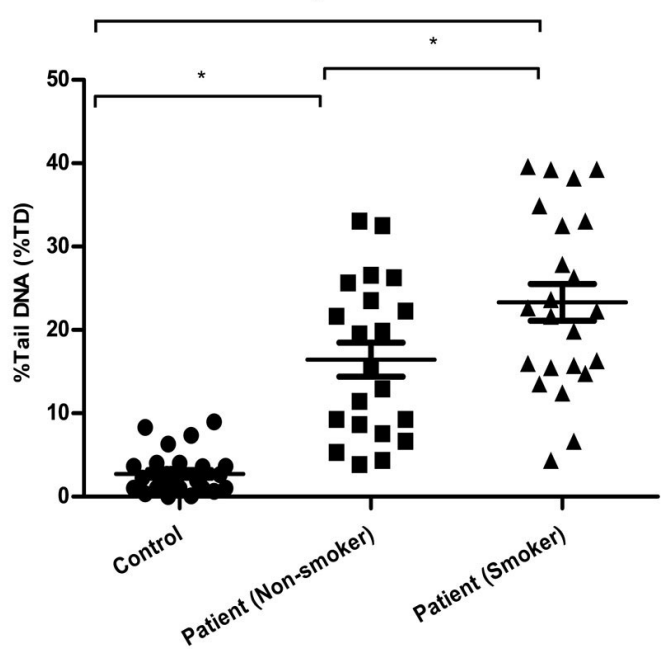

B

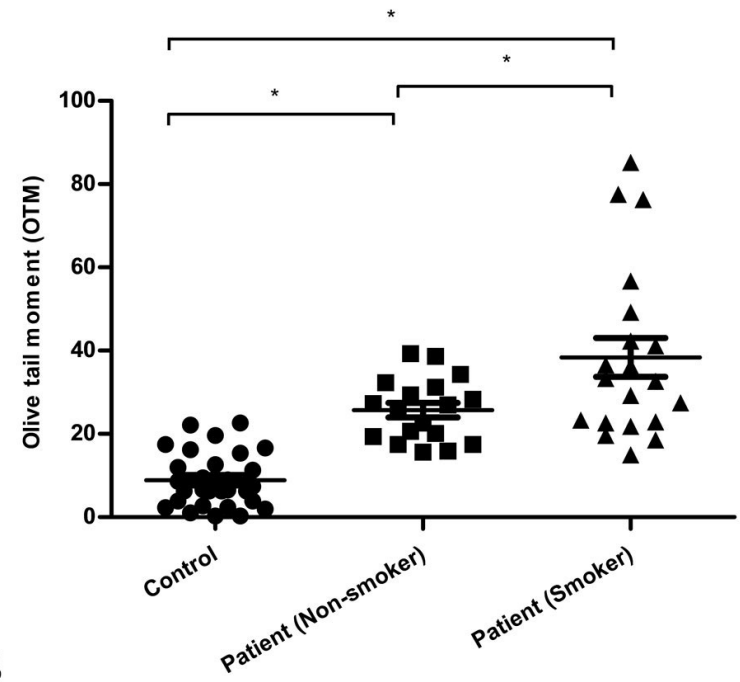

Figure 4. Observed DNA damage based on smoking history. (A) \%Tail DNA (\%TD), and (B) Olive tail moment (OTM) among control subjects, patient's smoker and patient's non-smoker groups. Statistical difference was tested by one-way ANOVA followed by Tukey's multiple comparison test. * $\mathbf{P}<0.05$ was taken as level of significance. 

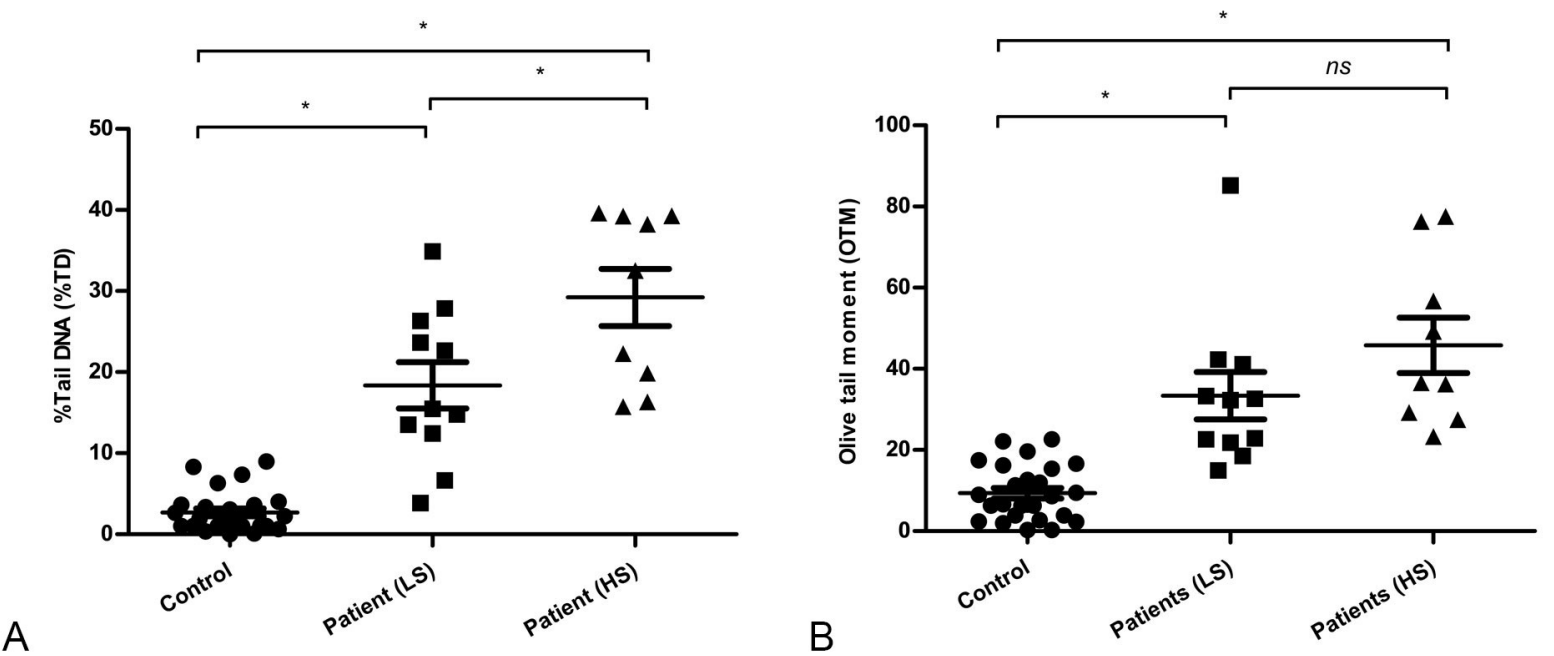

Figure 5. Observed DNA damage based on patients smoking exposure. (A) \%Tail DNA (\%TD), and (B) Olive tail moment (OTM) among control subjects, patient's lighter smoker (LS) and patient's heavy smoker (HS) groups. Statistical difference was tested by one-way ANOVA followed by Tukey's multiple comparison test. * $\mathbf{P}<\mathbf{0 . 0 5}$ was taken as level of significance. 'ns' $=$ not significant.

abnormalities and gene mutations [37]. Although DSBs is often repaired by two pathways, homologous recombination and nonhomologous end-joining (NHEJ), these genes are downregulated in long term carcinogenesis exposure [38]. Carcinogen containing cigarette smoking induced a lot of oxidative damage causing DNA oxidative adducts together with SSBs and DSBs.

Long term smoking history and intensity are linked to more advanced disease and severity. Here, BC patients having heavy smoking (HS) history had higher DNA damage even compare to patients with lighter smoker (LS) patients and non-smoker patients, which confirmed the previous finding [26, 34]. $\mathrm{BC}$ is commonly occurred in aged population due to their long term exposure to the carcinogen and genomic instability [39, 40]. In this study, significant DNA damages were also observed in older BC patients. NMIBC patients had also high DNA damage, which may be vulnerable because of cell cycle checkpoint delayed or altered DNA repair capacity that may trend to convert MIBC [41]. Thus, cigarette smoke may predominantly affect the structural integrity of the DNA in BC patients, which is strictly linked to cancer severity and rapid progression.

Finally, this study demonstrated the utility of the ACA technique for detecting DNA damage in $\mathrm{BC}$ patients and basal DNA damage in healthy Bangladeshi population. In future, the results of this study may be applied to analyze other environmental genotoxicants as well as chemotherapeutic agents that are responsible for DNA damage as well as revealing the genetic characteristics of bladder cancer, and finding the more efficient strategies to prevent it.

\section{Funding}

This research has been financially supported by Bangladesh Medical Research Council (BMRC), Bangladesh.

\section{Ethics approval and consent to participate}

Written consent was obtained from patients for the use of their biological samples for research purposes. This research has been performed in accordance with the Declaration of Helsinki.

Author contributions
YK designed the study, JI performed the study and wrote the first YK designed the study, JI performed the study and wrote the first draft of the manuscript. All authors read and approved the final manuscript.

\section{Competing interests}

The authors declare that they have no conflict of interest.

\section{References}

1. Ferlay J, Soerjomataram I, Dikshit R, Eser S, Mathers C, Rebelo M, Parkin DM, Forman D, Bray F: Cancer incidence and mortality worldwide: sources, methods and major patterns in GLOBOCAN 2012. International journal of cancer 2015, 136(5): E359-E386.

2. Hou L, Hong X, Dai M, Chen P, Zhao H, Wei Q, Li F, Tan W: Association of smoking status with prognosis in bladder cancer: A meta-analysis. Oncotarget 2017, 8(1): 1278-1289.

3. van Roekel EH, Cheng KK, James ND, Wallace DMA, Billingham LJ, Murray PG, Bryan RT, Zeegers MP: Smoking is associated with lower age, higher grade, higher stage, and larger size of malignant bladder tumors at diagnosis. International journal of cancer 2013, 133(2): 446-454.

4. Lodewijk I, Dueñas M, Rubio C, Munera-Maravilla E, Segovia C, Bernardini A, Teijeira A, Paramio J, Suárez-Cabrera C: Liquid Biopsy Biomarkers in Bladder Cancer: A Current Need for Patient Diagnosis and Monitoring. International journal of molecular sciences 2018, 19(9): 2514.

5. Hosen MB, Salam MA, Islam MF, Hossain A, Hawlader MZH, Kabir Y: Association of TP53 gene polymorphisms with susceptibility of bladder cancer in Bangladeshi population. Tumor Biology 2015, 36(8): 6369-6374.

6. Stern MC, Umbach DM, van Gils CH, Lunn RM, Taylor JA: DNA repair gene XRCC1 polymorphisms, smoking, and bladder cancer risk. Cancer Epidemiology and Prevention Biomarkers 2001, 10(2): 125-131.

7. Masaoka H, Matsuo K, Ito H, Wakai K, Nagata C, Nakayama T, Sadakane A, Tanaka K, Tamakoshi A, Sugawara Y: Cigarette smoking and bladder cancer risk: an evaluation based on a systematic 
review of epidemiologic evidence in the Japanese population. Japanese journal of clinical oncology 2016, 46(3): 273-283.

8. Tao L, Xiang Y-B, Wang R, Nelson HH, Gao Y-T, Chan KK, Mimi CY, Yuan J-M: Environmental tobacco smoke in relation to bladder cancer risk - the Shanghai bladder cancer study. Cancer Epidemiology and Prevention Biomarkers 2010, 19(12): 3087-3095.

9. Dietlein F, Thelen L, Reinhardt HC: Cancer-specific defects in DNA repair pathways as targets for personalized therapeutic approaches. Trends in genetics 2014, 30(8): 326-339.

10. Moktar A, Ravoori S, Vadhanam MV, Gairola CG, Gupta RC: Cigarette smoke-induced DNA damage and repair detected by the comet assay in HPV-transformed cervical cells. International journal of oncology 2009, 35(6): 1297-1304.

11. Zhou W, Liu G, Miller DP, Thurston SW, Xu LL, Wain JC, Lynch TJ, Su L, Christiani DC: Polymorphisms in the DNA repair genes $\mathrm{XRCC} 1$ and ERCC2, smoking, and lung cancer risk. Cancer Epidemiology and Prevention Biomarkers 2003, 12(4): 359-365.

12. Hoffmann H, Högel J, Speit G: The effect of smoking on DNA effects in the comet assay: a meta-analysis. Mutagenesis 2005, 20(6): 455-466.

13. Valavanidis A, Vlachogianni T, Fiotakis K: Tobacco smoke: involvement of reactive oxygen species and stable free radicals in mechanisms of oxidative damage, carcinogenesis and synergistic effects with other respirable particles. International journal of environmental research and public health 2009, 6(2): 445-462.

14. Fortini P, Pascucci B, Parlanti E, D'errico M, Simonelli V, Dogliotti E: 8-Oxoguanine DNA damage: at the crossroad of alternative repair pathways. Mutation Research/Fundamental and Molecular Mechanisms of Mutagenesis 2003, 531(1): 127-139.

15. Hirao Y, Kim W-J, Fujimoto K: Environmental factors promoting bladder cancer. Current opinion in urology 2009, 19(5): 494-499.

16. Hosen MB, Islam J, Salam MA, Islam MF, Hawlader MZH, Kabir $\mathrm{Y}$ : N-acetyltransferase 2 gene polymorphism as a biomarker for susceptibility to bladder cancer in Bangladeshi population. AsiaPacific Journal of Clinical Oncology 2015, 11(1): 78-84.

17. Paz-y-Mino C, Cumbal N, Sánchez ME: Genotoxicity studies performed in the Ecuadorian population. Molecular biology international 2012, 2012: 598984.

18. Bowman KJ, Al-Moneef MM, Sherwood BT, Colquhoun AJ, Goddard JC, Griffiths TL, Payne D, Singh S, Butterworth PC, Khan MA: Comet assay measures of DNA damage are predictive of bladder cancer cell treatment sensitivity in vitro and outcome in vivo. International journal of cancer 2014, 134(5): 1102-1111.

19. Zainol M, Stoute J, Almeida GM, Rapp A, Bowman KJ, Jones GD, Ecvag: Introducing a true internal standard for the Comet assay to minimize intra-and inter-experiment variability in measures of DNA damage and repair. Nucleic acids research 2009, 37(22): e150-e150.

20. McKeown S, Robson T, Price M, Ho E, Hirst D, McKelvey-Martin $\mathrm{V}$ : Potential use of the alkaline comet assay as a predictor of bladder tumour response to radiation. British journal of cancer 2003, 89(12): 2264-2270.

21. Tice RR, Agurell E, Anderson D, Burlinson B, Hartmann A, Kobayashi H, Miyamae Y, Rojas E, Ryu JC, Sasaki Y: Single cell gel/comet assay: guidelines for in vitro and in vivo genetic toxicology testing. Environmental and molecular mutagenesis 2000, 35(3): 206-221.

22. Wilson D, Wakefield M, Owen N, Roberts L: Characteristics of heavy smokers. Preventive Medicine 1992, 21(3): 311-319.

23. Nadin SB, Vargas-Roig LM, Ciocca DR: A silver staining method for single-cell gel assay. Journal of Histochemistry \& Cytochemistry 2001, 49(9): 1183-1186

24. Końca K, Lankoff A, Banasik A, Lisowska H, Kuszewski T, Góźdź S, Koza Z, Wojcik A: A cross-platform public domain PC imageanalysis program for the comet assay. Mutation Research/Genetic Toxicology and Environmental Mutagenesis 2003, 534(1): 15-20.

25. Duez P, Dehon G, Kumps A, Dubois J: Statistics of the Comet assay: a key to discriminate between genotoxic effects. Mutagenesis 2003, 18(2): $159-166$

26. Jin F, Thaiparambil J, Donepudi SR, Vantaku V, Piyarathna DWB, Maity S, Krishnapuram R, Putluri V, Gu F, Purwaha P: Tobaccospecific carcinogens induce hypermethylation, DNA adducts, and DNA damage in bladder cancer. Cancer Prevention Research 2017, 10(10): 588-597.

27. Crallan R, Georgopoulos NT, Southgate J: Experimental models of human bladder carcinogenesis. Carcinogenesis 2005, 27(3): 374-381.

28. Sanyal S, Festa F, Sakano S, Zhang Z, Steineck G, Norming U, Wijkström H, Larsson P, Kumar R, Hemminki K: Polymorphisms in DNA repair and metabolic genes in bladder cancer. Carcinogenesis 2004, 25(5): 729-734.

29. Benhamou S, Sarasin A: Variability in nucleotide excision repair and cancer risk: a review. Mutation Research/Reviews in Mutation Research 2000, 462(2): 149-158.

30. Zeegers MP, Tan FE, Dorant E, van den Brandt PA: The impact of characteristics of cigarette smoking on urinary tract cancer risk: a meta-analysis of epidemiologic studies. Cancer 2000, 89(3): 630-639.

31. Dhawan A, Bajpayee M, Parmar D: Comet assay: a reliable tool for the assessment of DNA damage in different models. Cell biology and toxicology 2009, 25(1): 5-32.

32. Kiriluk KJ, Prasad SM, Patel AR, Steinberg GD, Smith ND: Bladder cancer risk from occupational and environmental exposures. In: Urologic Oncology: Seminars and Original Investigations: 2012: Elsevier; 2012; 30(2): 199-211.

33. Gu J, Wu X: Genetic susceptibility to bladder cancer risk and outcome. Personalized medicine 2011, 8(3): 365-374.

34. Rojas E, Valverde M, Sordo M, Ostrosky-Wegman P: DNA damage in exfoliated buccal cells of smokers assessed by the single cell gel electrophoresis assay. Mutation Research/Genetic Toxicology 1996, 370(2): 115-120.

35. Olive PL, Banáth JP, Durand RE: Heterogeneity in radiation-induced DNA damage and repair in tumor and normal cells measured using the" comet" assay. Radiation research 1990, 122(1): 86-94.

36. Zhang M, Cao G, Guo X, Gao Y, Li W, Lu D: A comet assay for DNA damage and repair after exposure to carbon-ion beams or X-rays in Saccharomyces cerevisiae. Dose-Response 2018, 16(3): 1559325818792467.

37. Garaj-Vrhovac V, Kopjar N: The alkaline Comet assay as biomarker in assessment of DNA damage in medical personnel occupationally exposed to ionizing radiation. Mutagenesis 2003, 18(3): 265-271.

38. Chang C-H, Chang C-L, Tsai C-W, Wu H-C, Chiu C-F, Wang R-F, Liu C-S, Lin C-C, Bau D-T: Significant association of an XRCC4 single nucleotide polymorphism with bladder cancer susceptibility in Taiwan. Anticancer Research 2009, 29(5): 1777-1782.

39. Taylor III JA, Kuchel GA: Bladder cancer in the elderly: clinical outcomes, basic mechanisms, and future research direction. Nature Reviews Urology 2009, 6(3): 135-144.

40. Aunan JR, Cho WC, Søreide K: The biology of aging and cancer: a brief overview of shared and divergent molecular hallmarks. Aging and disease 2017, 8(5): 628-642.

41. de MC Gontijo ÁM, Elias FN, Salvadori DM, de Oliveira MLC, Correa LA, Goldberg J, Trindade JCdS, de Camargo JLV: Singlecell gel (comet) assay detects primary DNA damage in nonneoplastic urothelial cells of smokers and ex-smokers. Cancer Epidemiology and Prevention Biomarkers 2001, 10(9): 987-993. 